\title{
Fertility Variation, Genetic Relatedness, and Their Impacts on Gene Diversity of Seeds From a Seed Orchard of Pinus thunbergii
}

\author{
By K. S. KANG ${ }^{1, *)}$, D. LINDGREN ${ }^{2)}$ and T. J. MulLiN ${ }^{3)}$
}

(Received 20 ${ }^{\text {th }}$ October 2003)

\begin{abstract}
Clonal differences in the number of male and female strobili were determined for five consecutive years in a clonal seed orchard of Pinus thunbergii in Korea. The effects of relatedness and clonal differences in reproductive development on gene diversity of seed (in terms of accumulated relatedness by status number) were estimated. While clonal differences were found, fertility variation was not large through all studied years. The orchard clones were divided into different regions and locations based on the geographical distribution and distance of natural stands that plus trees were selected from. Assuming that there was no relatedness among regions, locations and clones, the status number $\left(N_{s}\right)$ was varied from 47.6 to 55.5 for five successive years. On average (pooling), $N_{s}$ was $92 \%$ of census number $(N)$. Assumed relatedness among regions, locations and/or clones decreased the status number. Effect of parental selection on relatedness and orchard management was also discussed.
\end{abstract}

Key words: fertility variation, status number, gene diversity, relatedness, Pinus thunbergii.

\section{Introduction}

Seed orchards, established with selected materials from several plus trees, are expected to provide large amounts of seeds with high genetic and physiological value. Maximizing genetic quality of seed crops from wind-pollinated orchards may require some intervention as the ideal panmictic situation is often violated due to self-pollination, genetic drift and pollen contamination from sources outside the orchard (ERIKSSON et al., 1973).

Seed orchard clones originating from different regions may differ in terms of reproductive phenology and output (MATZIRIS, 1994). Subsets of synchronized clones originating from the same region, which may be more related, can give rise to subpopulation structure within the orchard (EL-KASSABY, 1989). These may in turn cause large numbers of empty or selfed seeds to be harvested from the orchard. Another consequence of large variation in reproductive phenology is the unequal contribution of the clones to the next generation.

Pinus thunbergii Parl. is considered a maritime pine and occurs naturally as small, disconnected populations in coastal areas of Korea and Japan (KIM et al., 1997). Genetic variation in natural stands of $P$. thunbergii has been studied (MIYATA and UBUKATA, 1994; KIM et al., 1997), but little is known about reproductive output and gene diversity of seeds from the seed orchards. This paper reports clonal and yearly variation in

1) Tree Breeding Division, Korea Forest Research Institute, 44-3 Omokchun, Kwonsun, Suwon, Kyonggi 441-350, Republic of Korea.

2) Department of Forest Genetics and Plant Physiology, Swedish University of Agricultural Sciences, SE-901 83, Umeå, Sweden.

$\left.{ }^{3}\right)$ Department of Forestry, N.C. State University, Box 8002, Raleigh, NC 27695-8002, USA.

*) Author to whom all correspondence should be addresses: KYU-SUK KANG, phone: +82 31290 1120, fax: +82 31292 8468. E-mail: kangks@foa.go.kr female and male strobilus production in a seed orchard of P. thunbergii. Gene diversity of seeds was estimated based on assessment of strobilus production and relatedness within and among sub-sets of orchard parents from different locations.

The aims of this study were: (1) to determine whether there are chronically good or poor strobilus producers in the seed orchard; (2) to examine how differences in strobilus production affect gene diversity of the seed orchard crop; and (3) to monitor how different degrees of relatedness among and within regions from different locations might affect status number of seed orchard crops.

\section{Materials and Methods \\ Assessment of reproductive development}

The seed orchard was located on Anmyon Island (lat. $36^{\circ} 3^{\prime} \mathrm{N}$, long. $126^{\circ} 2^{\prime} \mathrm{E}$ and alt. $35 \mathrm{~m}$ ), Chung-Nam province, in the western part of Korea. The orchard was established in 1979 and managed by the Korean Forest Research Institute. The orchard contained near-equal numbers of ramets from 88 clones, distributed randomly over 4 ha. The ortets were plus trees selected in natural stands or plantations, distributed throughout the Republic of Korea. Two years after grafting, ramets were out-planted at $5 \times 5 \mathrm{~m}$ spacing.

Initially, six ramets per clone were randomly selected for sampling from each of 60 clones, although some ramets were subsequently lost. The numbers of male and female strobili were counted for five consecutive years from 1995 through 1999. The same ramets were assessed in each year. Female strobili were counted over the whole tree, while the numbers of male strobili were estimated by multiplying the average number of strobili per branch by the total number of branches bearing male strobili.

\section{Grouping}

Orchard genotypes (60 clones) were assigned to 4 regions, 13 sub-regions and 21 locations based on the geographic origin of the selected ortets in order to predict the effect of genetic relatedness among and within population subdivisions (Figure 1). The sizes of regions, sub-regions and locations corresponded approximately to province, county and township, respectively.

\section{Fertility variation}

Fertility variation was estimated by the sibling coefficient, $\Psi$ (KANG and EL-KASSABY, 2002) as follows:

$$
\begin{aligned}
\Psi & =N \sum_{i=1}^{N} p_{i}=N \sum_{i=1}^{N}\left(\frac{f_{i}+m_{i}}{2}\right)^{2} \\
& =0.25\left(\psi_{f}+\psi_{m}+2 r \sqrt{\left(\psi_{f}-1\right)\left(\psi_{m}-1\right)}\right)+0.5
\end{aligned}
$$

where $N$ is the number of genotypes, $p_{i}$ is the contribution of genotype $i, f_{i}$ is the contribution as female and $m_{i}$ is the contribution as male. $\psi_{f}$ is the fertility variation of female parents; $\psi$ $=C V_{f}^{2}+1$ and $\psi_{m}$ is that of male parents; $\psi_{m}=C V_{f}^{2}+1$ and $r$ is the correlation coefficient between female and male strobilus production. $C V_{f}$ and $C V_{m}$ are coefficients of variation in female and male strobilus production. 


\section{Group coancestry and status number}

Coancestry is the probability of identity by descent (compared to some reference) of genes from two individuals. Group coancestry $(\Theta)$ for a population (COCKERHAM, 1967) is the average of all coancestries between population members, including self-coancestry and reciprocals. Group coancestry is also the probability of identity by descent of two genes taken at random (with replacement) from the gene pool of the population.

In this study, we illustrate the consequences when clones are differently related depending on their assignment to regions, sub-regions and locations. Individual genotypes are assumed to be non-inbred. Alternative scenarios describing population differentiation on the basis of relatedness within and among population subdivisions were assessed as:

A) Scenario 1: when all orchard genotypes are unrelated.

$$
\Theta=\frac{0.5 N}{N^{2}}=\frac{0.5}{N}
$$

where 0.5 is self-coancestry (i.e., relatedness of a clone with itself for non-inbred clones) in a coancestry matrix.

B) Scenario 2: when all orchard genotypes are half-sib relatives.

$$
\Theta=\frac{0.5 N+0.125\left(N^{2}-N\right)}{N^{2}}=\frac{0.5+0.125(N-1)}{N}
$$

C) Scenario 3: relatedness was assumed to vary according to the closeness of origins of the genotypes. The group coancestry was calculated as the average of the elements (coancestry values for individual pairs) in a coancestry matrix of size $60 \times 60$ (one element for each possible relationship among the $60 \mathrm{popu}-$ lation members) as follows:

$$
\Theta=\frac{\sum_{i=1}^{L} \sum_{j=1}^{J_{i}} \sum_{k=1}^{K_{i j}} \sum_{i=1}^{L_{i j k}} \theta_{i j k l}}{N^{2}}
$$

where pairs of clones from different regions and from different sub-regions within a region were assumed to have $\theta_{i}=\theta_{j}=0$; from different locations within a sub-region $\theta_{k}=0.05$; and within a location $\theta_{l}=0.125$ (half-sibs).

Status number $\left(N_{s}\right)$ was defined by LINDGREN et al. (1996) as half the inverse of group coancestry $(\Theta)$. When there is fertility variation among genotypes, it can be calculated as a function of the sibling coefficient, $\Psi$ (c.f., LINDGREN and MULLIN, 1998) as:

$$
N_{s}=\frac{0.5}{\Theta \Psi}
$$

\section{Results}

\section{Fertility variation}

Average strobilus production, coefficient of variation, and correlation between female and male strobilus production are presented in Table 1. Strobilus production was good in both 1997 and 1998. Female strobilus production peaked in 1998 and male strobilus production was highest in 1997. On average, each ramet produced 123.0 female strobili and 446.5 male strobili (Table 1). The coefficient of variation for male strobilus production decreased as grafts aged.

Total fertility variation $(\Psi)$ was not so high even though differences among clones were statistically significant in all 5 years (data not shown) for female and male strobilus production (Table 2). Also, differences in fertility variation between female and male strobilus production were not large. Sibling coefficients for female and male $\left(\psi_{f}, \psi_{m}\right)$ varied from 1.10 to 1.15 and from 1.26 to 1.80 (Table 1). Based on the five-year average (pooling), sibling coefficients were 1.09, 1.27 and 1.09 for maternal $\left(\psi_{f}\right)$, paternal $\left(\psi_{m}\right)$ and total $(\Psi)$ fertility variation, respectively (Tables 1 and 2 ).

\section{Status number}

Assuming there was no relatedness among regions, subregions, locations and clones (Scenario 1; $\theta_{i}=\theta_{j}=\theta_{k}=\theta_{l}=0$ ), fertility variation alone caused the status number to vary from 47.6 to 55.5 during the five-year study period (Table 2). On average (pooling), the status number was calculated to be $92 \%$ of census number. Status numbers were found greater when the sibling coefficient was smaller.

If the orchard parents were all half-sibs and there were $12.5 \%$ relatedness among regions, sub-regions and locations (Scenario 2; $\theta_{i}=\theta_{j}=\theta_{k}=\theta_{l}=0.125$ ), the status number of orchard crops $\left(N_{s}\right)$ varied from 3.0 to 3.5. Assuming that clones from the same location were half-sibs $\left(\theta_{l}=0.125\right)$ and there were $5 \%$ relatedness among locations $\left(\theta_{k}=0.05\right)($ Scenario 3$)$, $N_{s}$ was ranged from 19.6 to 22.8 (Table 2).

\section{Discussion \\ Fertility variation}

Numbers of male and female strobili were found to vary among clones and among years (Table 1). Clonal differences in strobilus production indicated that a few prolific clones could contribute a large proportion of the seeds, particularly those

\begin{tabular}{|c|c|c|c|c|c|c|c|c|c|c|c|c|}
\hline & \multicolumn{2}{|c|}{1995} & \multicolumn{2}{|c|}{1996} & \multicolumn{2}{|c|}{1997} & \multicolumn{2}{|c|}{1998} & \multicolumn{2}{|c|}{1999} & \multicolumn{2}{|c|}{ Average } \\
\hline & q & $\delta$ & ㅇ. & $\hat{0}$ & 우 & 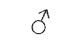 & ㅇ & $\delta$ & 우 & $\delta$ & ㅇ & $\delta$ \\
\hline Average & 92.3 & 368.4 & 95.3 & 393.6 & 158.4 & 758.6 & 173.8 & 326.8 & 95.3 & 384.9 & 123.0 & 446.5 \\
\hline$C V_{f} \& C V_{m}$ & 0.389 & 0.893 & 0.354 & 0.850 & 0.355 & 0.571 & 0.469 & 0.534 & 0.321 & 0.509 & 0.301 & 0.521 \\
\hline$\psi_{f} \& \psi_{m}{ }^{a)}$ & 1.15 & 1.80 & 1.13 & 1.72 & 1.13 & 1.33 & 1.22 & 1.29 & 1.10 & 1.26 & 1.09 & 1.27 \\
\hline$r^{\text {b) }}$ & \multicolumn{2}{|c|}{0.133} & \multicolumn{2}{|c|}{0.119} & \multicolumn{2}{|c|}{-0.127} & \multicolumn{2}{|c|}{0.019} & \multicolumn{2}{|c|}{-0.117} & \multicolumn{2}{|c|}{-0.033} \\
\hline
\end{tabular}

Table 1. - Average, coefficient of variation $\left(C V_{f} \& C V_{m}\right)$, sibling coefficient $\left(\psi_{f} \& \psi_{m}\right)$ and correlation coefficient $(r)$ for female and male strobilus production over 5 -year assessment period in a clonal seed orchard of Pinus thunbergii.

a) $\psi_{f}$ is the fertility variation of seed parents $\left(\psi_{f}=C V_{f}^{2}+1\right)$ and $\psi_{m}$ is that of pollen parents. $f$ and $m$ represent female and male, respectively.

b) phenotypic correlation coefficient between numbers of female and male strobili per clone. 
Table 2. - Sibling coefficient $(\Psi)$ and status number $\left(N_{s}\right)$ for gamete gene pool over five successive years. $N_{s}$ were calculated in the cases of where relatedness was assumed to be zero (unrelated), all half-sibs and various. $\theta_{i}=0$ for all alternatives.

\begin{tabular}{|c|c|c|c|c|c|c|}
\hline & 1995 & 1996 & 1997 & 1998 & 1999 & Pooled \\
\hline$\Psi$ & 1.26 & 1.23 & 1.10 & 1.13 & 1.08 & 1.09 \\
\hline \multicolumn{7}{|c|}{ Scenario 1) $\theta_{j}=\theta_{k}=\theta_{l}=0$ (unrelated) } \\
\hline$N_{s}$ & 47.6 & 48.8 & 54.5 & 53.2 & 55.5 & 55.1 \\
\hline \multicolumn{7}{|c|}{ Scenario 2) $\theta_{j}=\theta_{k}=\theta_{l}=0.125$ (all half-sibs) } \\
\hline$N_{s}$ & 3.0 & 3.1 & 3.5 & 3.4 & 3.5 & 3.5 \\
\hline \multicolumn{7}{|c|}{ Scenario 3) $\theta_{j}=0, \theta_{k}=0.05, \theta_{l}=0.125$} \\
\hline$N_{s}$ & 19.6 & 20.1 & 22.4 & 21.8 & 22.8 & 22.6 \\
\hline
\end{tabular}

harvested during the poor seed year (ToDHUnTER and PoLK, 1982; YING et al., 1985). Although each clone could have its own production rhythm, clonal differences in strobilus production are much less pronounced in good seed years with fewer deviations from random crossing (O'REILLY et al., 1982). It would also be expected to see less difference among ramets in good or moderate seed years (EL-KASSABY et al., 1989).

Variation in reproductive output and phenology has been studied in many forest tree species (ERIKSSON et al., 1973; Schoen et al., 1986; REYNolds and El-Kassaby, 1990; MATZIRIS, 1993; BURCZYK and CHALUPKA, 1997). Such variation accumulates relatedness and inbreeding in the progeny, and consequently affects the genetic quality of seed. It was reported by Kwon et al. (1987) that Pinus thunbergii showed a pollination period of less than a week, meaning that clonal variation of strobilus production would be more important than phenology in this species.

We observed only one reproductive phase to make our determinations of clone fertility. However, there may be many other important phases between strobilus development and viable offspring (Siegismund et al., 1996; RUotsalainen and NikKANEN, 1989) that affect reproductive output. In general, the quantitative number of strobili is the most important contributing factor to genetic composition of seed crop in the seed orchards, especially for species such as Pinus thunbergii where most trees have a pollination period of less than a week (KwON et al., 1987). Similar observations have been made for Pinus densiflora (JANG, 1993) and Pinus sylvestris (KARKKAINEN and SAVOlAinen, 1993).

Fertility variation was relatively low throughout the fiveyear period (Table 2), compared to the review by KANG et al. (2003). Clone fertility and fertility variation are likely to change over time even if none of the clones are replaced or removed. A given clone may reach its maximum reproductive output more slowly or more quickly than average, and may vary greatly from year to year. Also, numbers of ramets per clone may become increasingly variable as the orchard ages, due to ramet mortality and silvicultural thinning to control density.

\section{Relatedness among plus trees}

For forest tree breeding, it is natural to see plus trees as the starting point and the reference (GREGORIUS and MULLER, 1975). If they were considered to be unrelated and non-inbred genotypes, we could monitor the accumulation of relatedness and inbreeding resulting from management of breeding population (KANG and LINDGREN, 1999). However, there might be weak relatedness among clones in first-generation seed orchards because selected plus trees located in close proximity to each other may share common ancestors. One of the plus

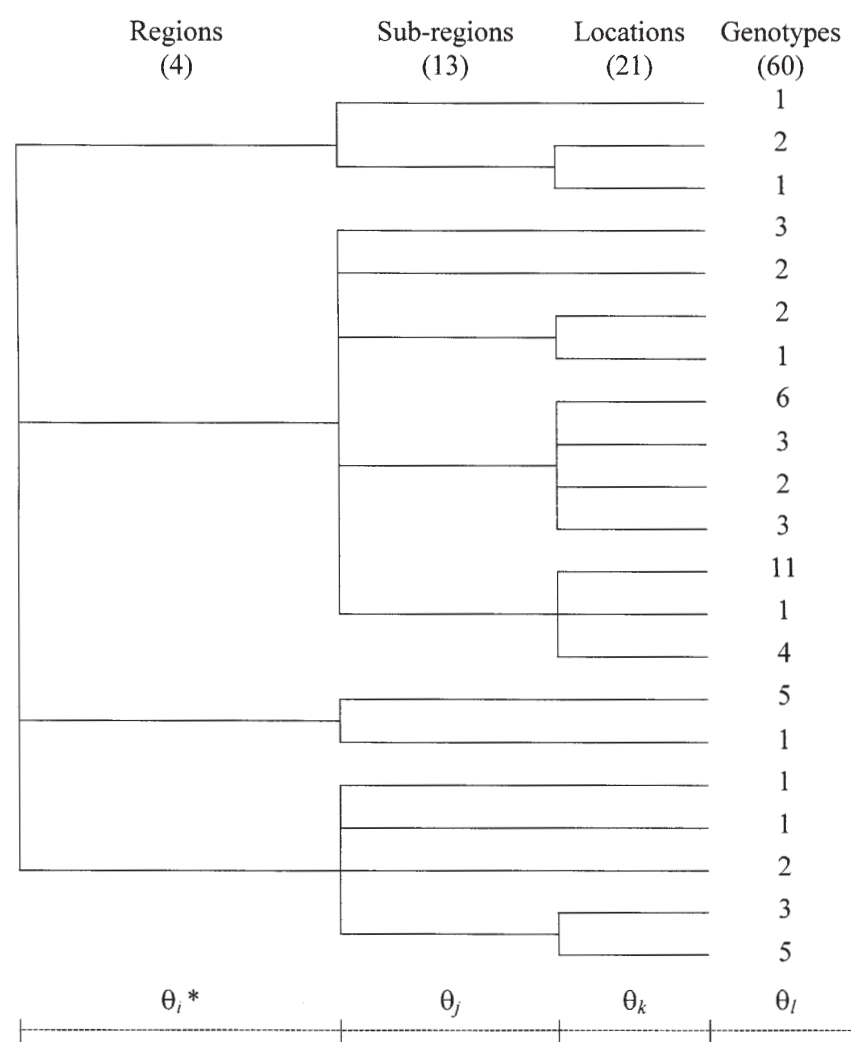

$* \theta_{i}, \theta_{j}, \theta_{k}$ and $\theta_{l}$ represent relatedness among regions, among subregions within the regions, among locations within the sub-regions, and among genotypes within the location, respectively.

Figure 1. - Grouping of 60 orchard clones based on the geographical distribution and distance of Pinus thunbergii stands where orchard clones were selected from.

tree selection criteria is that plus trees should be widely separated to avoid close relatedness. There have no doubt been exceptions in practice, as there were a few plus trees in this orchard that originated from the same place (Fig. 1). These probably have higher probability to be relatives and thus higher relatedness.

It seems to be logical that relatedness among plus trees within the same location is higher than relatedness among plus trees selected in different locations and regions. The status number was, on average, 22.6 when orchard clones within the same location were assumed to be all half sibs $\left(\theta_{l}=0.125\right)$ and there was a little relatedness among locations $\left(\theta_{k}=0.05\right)$ (Table 2). Clones are unlikely to be all half sibs even if they originated from the same location, and thus $N_{s}$ would more likely be much higher. It is, however, quite uncertain how much the spatial distance and genetic variation can explain relatedness among trees and among populations.

It is theoretically expected that the genetic variance within sib-ships will be lower in crosses between related, inbred parents than in crosses between non-inbred parents. It was proved practically in a Norway spruce by ANDERSSON et al. (1974). It is obvious that natural selection, random genetic drift and mutation promote population differentiation, while phenotypic plasticity and gene flow delay or prevent the differentiation (see ERIKSSON, 1998 for review).

Relationship between genetic variation (or genetic distance) and relatedness may depend on evolutionary forces (GREGORIUS and Muller, 1975), which could be positive or negative. For inbreeding species (or inbred lines), genetic variation within a population is generally smaller than that among populations 
(Lindgren and Gregorius, 1976; HARDNER and PotTs, 1995) and relatedness within a population could be higher than among populations. For out-crossing species, however, it could be an opposite situation from the inbreeding species. For mixed-mating species like most conifers, it is hard to find out the general trend of the relationship between genetic variation and relatedness within and among populations.

\section{Status number}

The concept "effective population size of an orchard" as found in the literature often includes variation in the reproductive success of orchard parents, and thus treats fertility as a property of the parent (e.g., MUONA and HARJU, 1989; KJÆR, 1996; BuRCZYK and CHALUPKA, 1997). It could be argued that differences in reproductive success are better seen as a characteristic of the resulting seed crop, and the relevant effective number is "status number of the seed orchard crop" (LINDGREN and MulLin, 1998). KANG and LINDGREN (1999) also developed status effective number $\left(N_{s}\right)$ in connection with fertility variation among orchard parents. In their study, status number of orchard crop depends upon the relatedness among parents and variation in reproductive success of the parents, not upon how the gametes unite (LINDGREN and MULLIN, 1998).

Accumulated group coancestry is the loss of proportional gene diversity. The loss of gene diversity in seed orchards and their crops, which is due to relatedness or fertility variation, is a relevant consideration for genetic diversity of plantations or breeding populations. On the other hand, pollen contamination will increase gene diversity of orchard crops. Thus, $N_{s}$ and $\Psi$ estimates are important parameters for management of seed orchards and establishment of next-generation breeding populations.

In seed orchards, status number is best described as the status number of orchard seeds (LINDGREN and MULLIN, 1998). Status number of the seed orchard itself is equivalent to the status number of the orchard seeds only when parents are unrelated, non-inbred and have equal fertility, and when there is no pollen contamination by outside sources. Clones of the studied seed orchard are grafts of plus trees selected from distribution areas, assuming that there is no relatedness among the plus trees. As discussed above, there might be a few plus trees in this orchard that originated from the same place, resulting in higher probability to be relatives and thus higher relatedness. Therefore, status number would be a better description of orchard seeds than the census number in seed orchards.

It is obvious that an orchard showing a small status number will produce seeds that are more related. Having only a few clones also leads to reduced levels of gene diversity in a plantation, and this may increase the risk of production loss due to insects or disease (ASKEW and BuRROws, 1983; SORENSEN and CREss, 1994). Assuming that the wild population from which the plus-trees were selected consists of unrelated, non-inbred founders, proportional gene diversity can be quantified as group coancestry and status effective number. Accumulation of group coancestry in the seed crops could be interpreted as the fraction of gene diversity lost in the domestication process. Thus, gene diversity can be seen as proportional to the reference population (i.e., wild forest)

\section{Acknowledgement}

This study was supported by the Korea Forest Research Institute, the Kempe Foundation and the Föreningen Skogsträdsförädling. Most of this work was done when the first author was a post-graduate student at the Department of For- est Genetics and Plant Physiology in the Swedish University of Agricultural Sciences (SLU-Umeå). Authors thank to an anonymous referee who gave valuable comments.

\section{References}

Andersson, E., JAnsson, R. and Lindgren. D. (1974): Some results from second generation crossings involving inbreeding in Norway spruce (Picea abies). Silvae Genet. 23: 34-43.

Askew, G. R. and Burrows, P. M. (1983): Minimum coancestry selection I. A Pinus taeda population and its simulation. Silvae Genet. 32: 125-131.

BurCZYK, J. and ChaluPKA, W. (1997): Flowering and cone production variability and its effect on parental balance in a Scots pine clonal seed orchard. Ann. Sci. For. 54: 129-144.

Cockerham, C. C. (1967): Group inbreeding and coancestry. Genetics 56: 89-104.

EL-KASSABY, Y. A. (1989): Genetics of Douglas-fir seed orchards: expectations and realities. In: Proc. 20 ${ }^{\text {th }}$ Southern Forest Tree Improvement Conference, pp. 87-109.

El-Kassaby, Y. A., Fashler, A. M. K. and Crown, M. (1989): Variation in fruitfulness in a Douglas-fir seed orchard and its effect on crop-management decisions. Silvae Genet. 38: $113-121$.

ERIKSSON, G. (1998): Evolutionary forces influencing variation among populations of Pinus sylvestris. Silva Fenn. 32: 173-184.

ERIKSson, G., Jonsson, A. and LindGren, D. (1973): Flowering in a clone trail of Picea abies L. Stud. For. Suec. 110: 45pp.

Gregorius, H. R. and Muller, G. (1975): Genetic structures in finite, open-pollinated plant populations: a model and its application to seed orchards. Theor. Appl. Genet. 46: 295-305.

HARDNER, C. M. and PotTs, B. M. (1995): Inbreeding depression and changes in variation after selfing in Eucalyptus globules ssp. globules. Silvae Genet. 44: 46-54.

JANG, K. W. (1993): Clonal variation in gamete production in a Pinus densiflora seed orchard: with an emphasis on the flowering amount, data, and pollen shedding density. M. A. Thesis. Korea University. 33pp.

KANG, K. S. and El-Kassaby, Y. A. (2002): Considerations of correlated fertility between genders on genetic diversity: Pinus densiflora seed orchard as a model. Theor. Appl. Genet. 105: 1183-1189.

KANG, K. S. and LINDGREN, D. (1999): Fertility variation among clones of Korean pine (Pinus koraiensis) and its implications on seed orchard management. For. Genet. 6: 191-200.

KANG, K. S., BILA, A. D., HARJU, A. M. and Lindgren, D. (2003): Fertility variation in forest tree populations. Forestry 76 : 329-344.

KarkKainen, K. and SAVOlainen, O. (1993): The degree of early inbreeding depression determines the selfing rate at the stage model and results from Pinus sylvestris (Scots pine). Heredity 71: 160-166.

KIM, Z. S., LEE, S. W. and Hwang, J. W. (1997): Genetic diversity and structure of natural populations of Pinus thunbergii in Korea. Silvae Genet. 46: 120-124.

KJÆR, E. D. (1996): Estimation of effective population number in a Picea abies (Karst.) seed orchard based on flower assessment. Scan. J. For. Res. 11: 111-121.

Kwon, Y. J., KIm, J. H., JANG, K. W., KIm, Y. J., Hwang, S. I., JANG, S. S. and CHO, R. M. (1987): Effect of flowering on seed production in a Pinus densiflora seed orchard. Res. Rep., Inst. For. Gen. Korea 23: 84-90.

Lindgren, D. and Gregorius, H. R. (1976): Inbreeding and coancestry. Proc. IUFRO Joint Meeting of Working Parties on Population and Ecological Genetics, Breeding Theory, Biochemical Genetics and Progeny Testing, Bordeaux, France. p. 49-72.

Lindgren, D. and Mullin, T. J. (1998): Relatedness and status number in seed orchard crops. Can. J. For. Res. 28: 276-283.

Lindgren, D., GeA, L. D. and JefFerson, P. A. (1996): Loss of genetic diversity monitored by status number. Silvae Genet. 45: $52-59$. 
MATZIRIS, D. I. (1993): Variation in cone production in a clonal seed orchard of Black pine. Silvae Genet. 42: 136-141.

MatziRis, D. I. (1994): Genetic variation in the phenology of flowering in Black pine. Silvae Genet. 43: 321-328.

MiYATA, M. and UBukATA, M. (1994): Genetic variation of allozymes in natural stands of Japanese black pine. J. Jpn. For. Res. 76: $445-455$.

MuOna, O. and HaRJu, A. (1989): Effective population size, genetic variability, and mating systems in natural stands and seed orchards of Pinus sylvestris. Silvae Genet. 38 221-228.

O'Reilly, C., PARKer, W. H. and Barker, J. E. (1982): Effect of pollen period and strobili number on random mating in a clonal seed orchard of Picea mariana. Silvae Genet. 31: 90-94.

REYNOLDS, S. and El-Kassaby, Y. A. (1990): Parental balance in Douglas-fir seed orchards-cone crop vs. seed crop. Silvae Genet. 39: 40-42.

Ruotsalainen, S. and NikKANEN, T. (1989): Variation in flowering of north Finnish clones in a Norway spruce seed orchard in central Finland. Pro. IUFRO working party, S2.02-11, 1988, Sweden. Eds). Stener, L. G. and Werner M. Norway spruce; Provenance, breeding and genetic conservation: p. $176-188$

Schoen, D. J., Denti, D. and Stewart, S. C. (1986): Strobilus production in a clonal white spruce seed orchard: Evidence for unbalanced mating. Silvae Genet. 35: 201-205.

Siegismund, H. R, KJÆR, E. D. and Nielsen, U. B. (1996): Mating system estimates and effective population numbers for an isolated noble fir (Abies procera) clonal seed orchard in Denmark. Can. J. For. Res. 26: 1135-1141.

Sorensen, F. C. and CREss, D. W. (1994.): Effects of sib mating on cone and seed traits in coastal Douglas-fir. Silvae Genet. 43: 338-345.

Todhunter, M. N. and Polk, R. B. (1982): Seed and cone production in a clonal orchard of Jack pine (P. banksiana). Can. J. For. Res. 12: 512-516.

Ying, C. C., Murphy, J. C. and Andersen, S. (1985): Cone production and seed yield of lodgepole pine grafts. For. Chron. 61: $223-228$.

\title{
Spatial Genetic Structure in Disturbed Populations of Quercus acutissima (Fagaceae)
}

\author{
By M. Y. Chung ${ }^{1)}$, M. G. Chung ${ }^{1,8)}$, E. R. MYers ${ }^{2)}$, J. M. ChunG ${ }^{3)}$, K.-J. KIM ${ }^{4)}$, C.-W. PARK ${ }^{5)}$, B.-Y. Sun ${ }^{6)}$ and J.-H. PAK ${ }^{7)}$
}

(Received $14^{\text {th }}$ January 2004)

\begin{abstract}
Quercus acutissima is a large deciduous tree of hillsides ranging from South Korea to Japan. It occurs in many plant communities, often as a pioneer species in monospecific stands which colonized gaps after gap formation. This study used multilocus allozyme genotypes mapped from two disturbed populations near farm houses in southern Korea to compare our results with previous studies conducted on undisturbed populations of trees in southern Korea. Coancestry measures $\left(f_{\mathrm{ij}}\right)$, RIPLEY's $L$-statistics, and WRIGHT's $F$-statistics were then calculat-

\footnotetext{
1) Department of Biology, Gyeongsang National University, Jinju 660-701, Republic of Korea;

2) Department of Life Science, South Suburban College, South Holland Illinois, USA;

3) Division of Specimen and Genetic Resources, National Arboretum, Korea Forest Service, Gyeonggi Province, 487-821, Republic of Korea;

4) Graduate School of Biotechnology, Korea University, Seoul 136-701, Republic of Korea;

5) School of Biological Sciences, Seoul National University, Seoul 151-742, Republic of Korea;

$\left.{ }^{6}\right)$ Faculty of Bioloical Sciences, Chonbuk National University, Chonju 561-756, Republic of Korea; and

7) Department of Biology, Kyungpook National University, Daegu 702-701, Republic of Korea.

${ }^{8}$ ) Corresponding author and address: Myong GI CHUnG, Department of Biology, Gyeongsang National University, Jinju 660-701, Republic of Korea. Telephone: +82-55-751-5953. Fax: +82-55-754-0086. Email: mgchung@nongae.gsnu.ac.kr
}

ed to examine the distribution of individuals and spatial genetic structure both within and between populations. RIPLEY's $L$ statistics indicated significant aggregation of individuals at interplant distances. A weak but significant positive fine-scale genetic structure at $10 \mathrm{~m}$ distance was detected in the two disturbed populations, which is consistent with the structure found in an inland, disturbed population in southern Korea. Estimates of near-distance $f_{\mathrm{ij}}$ in the two populations ( 0.020 and 0.036 ) were considerably lower than that expected for half-sibs (0.125) under random mating, suggesting secondary seed dispersal and substantial overlap of seed shadows. The levels of genetic diversity within the two disturbed populations of $Q$. acutissima were found to be comparable to the within-mean for populations of other oak species. Significant deficits of heterozygosity were detected in both populations, probably due to several parent-offspring and sib matings. Finally, a significant but low differentiation between the two disturbed populations of $Q$. acutissima was found, which is likely to be attributable to long-distance pollen movement by wind, which should enhance homogeneity of allele frequencies between adjacent local oak populations.

Key words: allozymes, disturbance, Fagaceae, Quercus acutissima, spatial genetic structure.

\section{Introduction}

Fine-scale genetic structure is evident within plant populations when the distribution of genetic variation among individ- 